\title{
Minority languages in Europe in the context of revitalizing activities
}

\section{[Mensinove jazyky v Europe v kontexte revitalizacnych aktivit]}

\author{
Katarina Slobodova Novakova - Katarina Kostialova - Daniela Kusnierova - \\ Lukas Kurajda
}

DOI: 10.18355/XL.2018.11.03.02

\begin{abstract}
The paper focuses on the analysis and presentation of the rescue research of unique German minority of mountain woodcutters called Huncokars. They live in western Slovakia, isolated in a mountainous environment, with a preserved culture and their own language. Due to the political situation and the unregulated rights of minorities in Slovakia in the 2 nd half of the 20th century this group has not been the subject of systematic research and scientific interest yet. Because of their isolation and specific socio-professional inclusion, they have preserved unique manifestations of material, spiritual and social culture, and their own unique language. This language belongs to the German Central Bavarian dialects and its occurrence outside the compact German speaking territories is unique in the territory of Slovakia. The main goal is to promote the efforts and activities aimed at language and culture revitalization, and then popularizing them. The expected benefit of revitalizing activities is a more visible reflection of local traditions today, and supporting values of bilingualism and multiculturalism. Huncokars represent a specific form of adaptation and group acclimatization in a different ethnic environment in the Small Carpathians. Therefore, we consider them as an important part of European and world cultural heritage. The ethnic group of Huncokars is a proof of the cultural diversity and multiculturalism of the ethnic and linguistic environment not only of Slovakia but also the entire Europe.

Key words: German minority, language, revitalization, cultural heritage, identity
\end{abstract}

\begin{abstract}
Anotácia
Príspevok je zameraný na analýzu a prezentáciu záchranného výskumu jedinečnej špecifickej nemeckej minority horských drevorubačov nazývaných Huncokári, žijúcej na západnom Slovensku, izolovane $\mathrm{v}$ horskom prostredí, so zakonzervovanou kultúrou a vlastným jazykom. Táto skupina nebola vzhl’adom na politickú situáciu a nepriznané práva menšinám v 2.polovici 20.storočia na Slovensku doteraz predmetom žiadnych systematických výskumov a vedeckého záujmu. Vd’aka izolovanosti a špecifickému socio-profesnému zaradeniu si uchovali jedinečné prejavy hmotnej, duchovnej a sociálnej kultúry a vlastný unikátny jazyk. Tento jazyk patrí k nemeckým stredobavorským nárečiam a jeho výskyt mimo kompaktných nemecky hovoriacich území je na území Slovenska jedinečný. Ciel’om je priblíženie snáh a aktivít zameraných na revitalizáciu jazyka a kultúry, a následne ich popularizácia. Očakávaným prínosom revitalizačných aktivít je viditelnější odraz lokálnych tradícií v súčasnosti, podpora hodnôt dvojjazyčnosti a multikulturality. Huncokári v Malých Karpatoch predstavujú špecifickú formu adaptácie a akulturácie skupiny $\mathrm{v}$ inoetnickom prostredí. Považujeme ich preto za významnú súčast' európskeho a celosvetového kultúrneho dedičstva. Etnická skupina Huncokárov je dokladom kultúrnej diverzity a multikultúrnosti etnického a jazykového prostredia Slovenska a celého európskeho priestoru.
\end{abstract}

Kl’účové slová: nemecká minorita, jazyk, revitalizácia, kultúrne dedičstvo, identita 


\section{Úvod}

$\mathrm{V}$ súčasnosti dochádza $\mathrm{v}$ rámci situácie menšinových jazykov v Európe $\mathrm{k}$ podstatným sociolingvistickým zmenám. Vzhl’adom k výrazným trendom jazykového posunu a asimilácie jazykov počet native speakers (d’alej používaný slovenský akvivalent "rodení hovoriaci") klesá. Výraznou novinkou minulých dekád je však zároveň fenomén tzv. new speakers (d'alej používaný termín "noví hovoriaci”), t.j. osôb, ktoré znalost' minoritného jazyka získali inou formou ako v prirodzenom procese socializácie.V danom kontexte dochádza tiež k flexibilite, resp. markantným premenám variantov a podôb mnohých jazykov (Šatava, 2017:323).

Na sklonku 20.storočia sme zaznamenávali zvýšený záujem lingvistov a najmä sociolingvistov o fenomén jazykovej asimilácie a postupného zániku viacerých jazykov (Krauss 1992; Brenzinger 2007; Austin-Sallabank 2011 a iní). Postupne sa však začal vytvárat' i akýsi "protiprúd”, presadzujúci naopak záujem o jazykovú revitalizáciu, chápanú nielen skriktne vedecky, ale najmä prakticky a aktivisticky. $\mathrm{Na}$ tomto poli revitalizačných snáh sa preslávil najmä Joshua Fishmann (1991, 2001), ktorý inšpiroval mnohých d'alších bádatel'ov a obrátil pozornost' na zastavenie či aspoň čiastočné spomalenie etnojazykovej asimilácie. U mnohých etník, napríklad Kataláncov, Baskov, Sámov v Euŕope, Maorioviov, či niektorých indiánskych kmeňov v severnej Amerike, sa to naozaj podarilo (Šatava, 2017:323 a n.).

$\mathrm{Na}$ Slovensku sa výskumný bádatel'ský tím na FF UCM pokúša podobným spôsobom, metódami, inšpirovaný výsledkami a skúsenost’ami v zahraničí, postupovat' v prípade kultúrnej a etnojazykovej revitalizácie nemeckej špecifickej minority označovanej ako Huncokári, žijúcej do polovice 20.storočia v izolovaných horských lokalitách západného Slovenska. Na Slovensku sa dodnes o podobný postup nikto nepokúsil, preto musíme vychádzat' zo skúseností zo zahraničia. Najbližšie máme možnost' porovnávat' dáta a výsledky $\mathrm{s}$ vel'mi úspešnými pokusmi o etnojazykovú revitalizáciu z pol'skej obce Wilamowice. Pri wilamowštine (wymysöryś) ide o malý germánsky jazyk v pol'skom Hornom Sliezsku s niekol'kými poslednými rodenými hovoriacimi, ktorý bol v ostatných rokoch vel'mi úspešne oživený (Olko-Wicherkiewicz-Borges, 2016: 17-149).

\section{Pôvod skupiny Huncokárov a ich jazyka}

V priebehu 18.storočia sa uskutočnilo osídl’ovanie západného Slovenska, najmä horských oblastí Malých a Bielych Karpát, nemeckým etnikom za špeciálnych podmienok. Viacerí feudáli a majitelia vel'kostatkov si pozývali nemeckých kolonistov z rôznych krajín osídl'ovat' ich majetky za obojstranne výhodných podmienok. Nemáme zatial podrobnejšie správy ani archívne materiály dokladajúce jednoznačné okolnosti, presné dôvody, roky a spôsob príchodu tejto skupiny na Slovensko. Vieme, že prišli z horského prostredia Rakúska či Nemecka na pozvanie vtedajších vlastníkov lesov, najmä rodiny Pálfiovcov. Vieme tiež, že boli profesne zameraní na prácu v lese, predpokladáme, že si priniesli spôsob života, adekvátny spoločenstvám, žijúcim a pracujúcim v horskom prostredí, a jemu zodpovedajúcimi hodnotovými orientáciami. Podl'a zatial' realizovaných archívnych výskumov to mohlo byt' najpravdepodobnejšie z južného alebo stredného Bavorska. Huncokári patria na Slovensku k poslednej, najmladšej vlne nemeckej kolonizácie, ktorá sa začala už niekedy v 13.storočí a pokračovala vo viacerých vlnách vo viacerých regiónoch Slovenska až do novoveku.

Podl'a bádatel'a a lingvistu Franza Beránka, ktorý realizoval na príkaz politických strán v 30. rokoch 20 . storočia výskumy medzi Nemcami na Slovensku, bol vznik sledovanej skupiny spätý s kolonizačnou aktivitou najväčšieho zemepána Bratislavskej župy, grófa Pálfiho. Ten v polovici 18.storočia povolal alpských lesných robotníkov s rodinami z juhu Dolného Rakúska a susedného Štajerska na svoje rozsiahle pozemky v Malých Karpatoch (Beranek 1943, 19). Rôzni autori uvádzajú

XLinguae, Volume 11, Issue 3, June 2018, ISSN 1337-8384, eISSN 2453-711X 
rozdielne lokality pôvodu lesných robotníkov. V kolektívnej pamäti potomkov týchto kolonistov sa zachovalo vedomie pôvodu z Tirolska, Štajerska, resp. Bavorska, alebo zo Sudet.

Huncokári boli do polovice 20.storočia izolovanou, vel'mi svojráznou a pomerne neznámou nemeckou minoritou v horskom území západného Slovenska. Boli lesníci a lesní robotníci, priniesli si z domovskej krajiny spôsob života, špecifický hodnotový systém a jazyk. Huncokári vykonávali prácu drevorubačov /stínačov, lesníkov a horárov, priniesli si a používali technologické postupy, ktoré na Slovensku v tom období ešte neboli známe. Z nemeckého pomenovania ich profesie Holzhacker a Holzfäller, nimi vyslovovaný ako Hulzhok, Hulcokr, vznikol v miestnom dialekte názov Huncokár, reps. Hulcokár, ktorý dnes chápeme ako etnonym, resp. exoetnonym. Pomernovanie Huncokár/ Huncokári dnes chápeme skôr ako nevhodný, ale v podstate jeho užívanie majoritou skupina toleruje. V odbornej historickej a etnologickej spisbe sa stretávame iba s používaním etnonymu Huncokár, preto ho na označenie a identifikovanie skúmanej skupiny používame i my, uvedomujúc si jeho limity.

Prvé záznamy o Huncokároch nájdeme v slovenských matrikách v 40 . rokoch 18.storočia, sú evidovaní ako katolíci, bez pôvodu či miesta narodenia, len $\mathrm{s}$ uvedením súčasného miesta pobytu (latinsky ex montibus, ex silvis) - z hôr, z lesov (+ názov lokality), alebo profesie (latinsky lignicida, lignisector)- drevorubač, stínač (Habáňová, 1992:67-68).

Huncokári žili v malokarpatských lesoch, v zemepanských horách či v mestských lesoch v horských osadách, samotách, hlboko v horách, rozptýlene dve tri rodiny spolu. Výnimku rozptýleného osídlenia tvorilo väčšie osídlenie na Piesku (dnes čast' mesta Modra, okres Pezinok), kde žilo 10 rodín. V súčasnosti poznáme 36 pôvodných huncokárskych lokalít hlboko v horách, vzdialených od seba 10-15km, vzdialených od podhorských miest a dedín minimálne 5-10 km, i niekol'ko menších už zaniknutých samôt. Jazyk a kultúra Huncokárov sa tak vyvíjali izolovane, vzhl'adom na geografickú oblast', ktorú obývali. Vd’aka tomu si zachovali i špecifické prejavy hmotnej, duchovnej i sociálnej kultúry až do polovice 20.storočia (Nováková 2014: 94-95). Známi boli svojou pomerne prísnou endogamiou, ktorej porušovanie sa začalo tolerovat' po prvej svetovej vojne. Mnohí príslušníci staršej generácie preto ešte v medzivojnovom období nevedeli vôbec po slovensky. Až do roku 1945 pretrvával v skupine bilingvizmus.

Vzdelávanie detí prebiehalo pomerne nevšednou formou. Deti nenavštevovali školy v mestách a dedinách, ale učili sa doma. Až do začiatku 20. storočia vyučovali deti Huncokárov najmä tzv. horskí učitelia v nemeckom jazyku špecifickou formou výučby priamo $\mathrm{v}$ horárňach $\mathrm{v}$ týždňových intervaloch. Deti $\mathrm{z}$ dvoch troch lokalít sa pravidelne stretávali $\mathrm{v}$ jednej domácnosti na vyučovaní. Hostitel'ská rodina počas týchto dní zabezpečila bývanie a stravu pre učitel'a i ostatné deti. Takto zabezpečili výučbu formou "turnusov" vo všetkých izolovaných horárňach. Deti učil učitel' základné počty, čítanie, písanie a náboženstvo. Vo viacerých lokalitách úlohu horského učitel'a na čas prevzal najstarší horár. Prvý škola pre huncokárske deti bola postavená na Piesku (dnes čast' mesta Modra). Vyučovanie v škole sa začalo 1. októbra 1890. Učitel'ovi Huncokári platili 50 grajciarov za každé školopovinné diet’a mesačne. Oficiálnym vyučovacím jazykom v tom čase bola mad'arčina, je však možné, že tieto deti boli vyučované po slovensky a nemecky. Až do zatvorenia školy (v roku 1945) sa tu vystriedalo vel'a učitel'ov, jeden rok tu tiež učil známy spisovatel' Fraňo Král' (1930). V čase Slovenského štátu (1938 - 1945) sa tu vyučovalo po nemecky (odtial' pochádza dnešný názov budovy - Nemecká škola). Po skončení vojny boli v roku 1945 na Slovensku všetky nemecké školy (teda aj tá na Piesku) zatvorené.

Do polovice 20.storočia sa $\mathrm{k}$ Huncokárom hlásilo približne tisíc l'udí. V roku 1928 odhadoval lingvista F. Beranek počet na osemsto, najnovšie výsledky 
rodinných genealógii naznačujú, že ich mohlo byt' ovel'a viac, v polovici 20. storočia najmenej tritisíc l'udí. Už v medzivojnovom období boli nútení (zmenou politickej situácie, čiatočne i zmenou vo vlastníctve lesov) st’ahovat' sa z izolovaných lokalít bližšie k mestečkám a obciam. Vel'ký vplyv na st'ahovanie z hôr malo zavedenie povinnej školskej dochádzky, pretože zo vzdialených lokalít neboli deti schopné každodenne dochádzat' dolu do mestečiek a dedín do školy.

Terénny materiál a komparácia dát z medzivojnového obdobia poukazuje na stav silnej izolovanosti Huncokárov od l’udí z miest a dedín v okolí Malých Karpát. Príčiny možno hladat' vo vlastných sídelných podmienkach, výnimočnosti profesie, ale i vo vnútornej uzavretosti, vyplývajúcej z vedomia cudzieho pôvodu, odlišnosti v kultúre, jazyku, správaní, hodnotách. Rovnost' vzt’ahov vyzdvihovali členovia skupiny ako významnú hodnotu medzil'udských väzieb a porovnávali ju s nerovným sociálnym postavením obyvatel'ov dediny, založenom na majetnosti. V retrospektívnych hodnoteniach členov skupiny sme sa stretávali s vyzdvihovaním kvalít vnútorného života spoločenstva, charakterizovaného silným vedomím spolupatričnosti. Na vyjadrenie týchto hodnôt a vzt'ahov užívali prirovnania ako: "sme jedna rodina, sme ako brat a sestra". Výskum v medzivojnovom období doložil previazanost' „všetkých so všetkými“ rôznymi druhmi a stupňami príbuzenských a rodinných vzt’ahov, umocňované susedskými a priatel'skými. Išlo o permanentné prerastanie rodinných vzt'ahov v spoločenské a naopak (Habáňová, 1991: 83). Rodiny boli mnohodetné, viacgeneračné, vo svojej forme jednoduché i rozšírené. Bývanie rozšírenej rodiny s niekol'kými manželskými pármi dospelých detí bolo vzhl'adom na kapacitu horární i deputát skôr dočasné, provizórne. Smerovalo k osamostatneniu mladých rodín získaním nového pracovného miesta s bytom (Habáňová, 1995:148). Snahy osamostatnit' sa boli panstvom podporované, i ked' do istej miery limitované počtom horských sídiel. Kam smerovali populačné prebytky, zatial' nemáme úplne doložené a zmapované.

Kontakty s dedinčanmi či mestom, dokonca i so vzdialenejšími horskými rodinami, mali Huncokári minimálne, preto i možnost' nájdenia si manželského partnera bola pomerne obmedzená. Okruh l'udí, s ktorými sa stretávali, bol malý. Sobáše medzi horskými l'ud'mi a dedinčanmi boli do medzivojnového obdobia takmer tabu, alebo len vel'mi zriedkavé. Dôvodov bolo pomerne vel'a, medzi najdôležitejšie patrili:

- $\quad$ obmedzené kontakty s majoritou vzhl'adom na vzdialenost' sídiel

- obojstranná nedôvera členov majority a minority

- $\quad$ pretrvávajúci bilingvizmus alebo neznalost' majoritného jazyka

- $\quad$ vysoká hodnota žien z vlastnej skupiny

- žiadaná a podporovaná endogamia, preferencia partnerov z vlastnej komunity

Huncokári vytvorili špecifické jazykovo i spoločensky pomerne uzavreté osídlenie, ktoré bolo po 2 . svetovej vojne z vel'kej časti rozptýlené, čast' Huncokárov násilne vyvezená, ostatní boli nútení sa pomerne rýchlo asimilovat'. Po druhej svetovej vojne bola čast' $\mathrm{z}$ nich nútene deportovaná do Nemecka na základe výsledkov druhej svetovej vojny a aplikáciu zákonov v ČSR o Nemcoch, zradcoch a kolaborantoch (Slobodová Nováková 2017). Zvyšok huncokárskych rodín sa pomerne rýchlo asimiloval s majoritným obyvatel'stvom, po presídlení do miest a dedín asimilácia prebehla za necelých 10 rokov. Povedomie o spolupatričnosti ku skupine bolo po druhej svetovej vojne a skúsenostiach Huncokárov s vysídlením a prenasledovaním tak dnes prežíva bud' prostredníctvom individuálnej pamäte potomkov alebo ako súčast' kolektívnej pamäte dnešných lokálnych spoločenstiev žijúcich v blízkosti niekdajších sídiel.

XLinguae, Volume 11, Issue 3, June 2018, ISSN 1337-8384, eISSN 2453-711X 
Jazyk Huncokárov je takmer zaniknutým a vel'mi ohrozeným nemeckým nárečím. Tento jazyk bol používaný niekol'ko storočí, ale $\mathrm{v}$ súčasnosti ho dokážu plynule používat' poslední traja rodení hovoriaci. Ostatných starších členov komunity, (roč. 1940 a vyššie), nazývame remembers - pamätníci; jazyku čiastočne rozumejú, ale neovládajú ho plynule, resp. poznajú z jazyka zopár výrazov či krátkych fráz. Mladá generácia komunity jazyk vôbec neovláda.

\section{Vývoj skupiny a vývoj výskumu}

Výskum nemeckej menšiny zostával do 80 . rokov 20. storočia na Slovensku obchádzanou, až tabuizovanou témou z politických, spoločenských i historických dôvodov. Možnosti rozvoja menšinových kultúr na Slovensku v uplynulých desat'ročiach neboli rovnaké pre každú tu žijúcu menšinu. Karpatskí Nemci patrili medzi tých, ktorí nemali možnosti rozvoja svojej kultúry a identity. K zmene status nemeckej minority prišlo po vzniku Slovenskej republiky v roku 1993, čím sa realizovalo ústavné právo menšín žijúcich na Slovensku - právo rozvíjat' vlastnú kultúru, zakladat' a udržiavat' si svoje vzdelávacie a kultúrne inštitúcie a povedomie.

Problematika Huncokárov nie je v slovenskej a európskej vedeckej spisbe, historickej, etnologickej či lingvistickej doposial' spracovaná takmer vôbec. Reprezentuje ju pár odborných štúdií a popularizačných článkov v rámci historických a etnologických analýz nemeckej národnostnej menšiny na území Slovenska.

Prvé pokusy o revitalizáciu Huncokárov boli sice zaznamenané už v medzivojnovom období, v prvej tretine 20.storočia, boli spojené s výskumami a snahami nemeckého lingvistu Franza Beránka. Pozadie jeho výskumu možno však spájat' s aktivitami nemeckých vzdelávacích spolkov, tzv. Deutscher Kulturverband, Karpatenverein, ktoré sa snažili o revitalizáciu národného povedomia nemeckej menšiny a o šírenie vel'konemeckých ideí v sudetonemeckej a karpatskej oblasti (Panczová 2011: 15-22, Beránek 1942). Prvé snahy o revitalizáciu sa realizovali najmä formou výskumov, publikovania odborných článkov a osvetových prednášok. Z hl'adiska autenticity záznamov o ich jazyku, duchovnej aj sociálnej kultúry možno použit' výskumy jazykovedca F. Beranku a W. Kuhna z 20. a 30. rokov 20. storočia. Vd’aka nim sa zachovalo niekol'ko unikátnych záznamov povestí a poverových rozprávaní $\mathrm{v}$ pôvodnom jazyku. Výskumu hodnotových orientácií, intra a extraskupinových vzt’ahov v živote Huncokárov sa venovala G. Habáňová z ústavu etnológie SAV, ktorá vykonala terénny výskum tejto skupiny až viac ako 40 rokov po jej rozptýlení (90.roky 20. storočia). Neskôr Z. Panczová vo svojej štúdii z roku 2011 priniesla spracovanie poverových rozprávaní Huncokárov práve z materiálov $\mathrm{F}$. Beránka.

Z hl'adiska jazykovedy je tu úplná absencia informácii i záujmu o štúdium dialektu sledovanej etnickej menšiny. $\mathrm{S}$ intenzívnym výskumom komunity a so záchranou tradičnej kultúry a jazyka sa začalo v roku 2014 na pôde FF UCM. Od tohto obdobia prebiehajú rozhovory a nahrávky nárečia, spomienkové rozprávania, výskumy listinných dokladov. Vd'aka týmto výskumom bolo možné identifikovat' hlavné gramatické a fonetické znaky tohto nárečia. $\mathrm{Na}$ základe doterajších lingvistických výskumov môžeme nárečie Huncokárov priradit’ k stredobavorským nárečiam. Výskyt špecifického stredobavorského nárečia mimo kompaktných nemecky hovoriacich území je na území Slovenska jedinečný (Fedič, 2014: 107-109). Čiastkové výsledky boli prezentované od roku 2015 na medzinárodných lingvistických a etnologických kongresoch. V roku 2017 sa začalo v komunite potomkov Huncokárov experimentálne $\mathrm{s}$ výučbou tohto nárečia. Impulz na revitalizáciu nárečia Huncokárov vzišiel priamo z prostredia Huncokárov a ich potomkov. Samotní Huncokári oslovili výskumníkov z UCM, aby im pomohli zmapovat' posledné zvyšky ich kultúry, zozbierat' archívne materiály, pomôct' $\mathrm{s}$ analýzou a interpretáciou, ako i pomôct' s revitalizáciou jazyka a kultúry, pretože sami Huncokári to nevedia, so slovami: „Pomôžte nám, zachráňte nás, lebo vymierame!” 
Ochota spolupracovat' a participovat' na záchrane jazyka svojich predkov umožnila dospiet' v snahách o revitalizáciu do súčasného štádia.

\section{Východiskové dáta pre výskum a revitalizáciu jazyka}

Huncokársky dialekt patrí $\mathrm{ku}$ hornonemeckým nárečiam, teda $\mathrm{ku}$ germánskym jazykom. Na základe doterajších analýz patria lokality pôvodu Huncokárov do dvoch oblastí. Prvá spomenutá oblast' patrí k prechodnej zóne medzi stredobavorským a juhobavorským nárečím. Druhá oblast' pôvodu, ktorá sa uchovala v kolektívnej pamäti Huncokárov, patrí k oblasti s juhobavorským nárečím. Medzi Huncokármi sa objavujú aj tendencie, že pochádzajú z Bavorska, čo by naznačovalo ich pôvod $\mathrm{v}$ oblastiach, kde prevládalo stredobavorské nárečie. Oblasti pôvodne osídl'ované nemecky hovoriacim obyvatel'stvom na dnešnom západnom Slovensku patria z lingvistického hl'adiska $\mathrm{k}$ horskonemeckým nárečiam. Oblasti osídl’ované nemecky hovoriacim obyvatel'stvom na strednom a východnom Slovensku, v oblasti Hauerland, na Spiši a v Above patria k nárečiam stredonemeckým. Do týchto oblastí prichádzali Nemci práve zo stredného Nemecka. Z tohto dôvodu sú medzi troma oblast'ami, v ktorých sa do dnešného dňa možno stretnút' $\mathrm{s}$ nemeckým nárečím, výrazné rozdiely. Najrozsiahlejšie oblasti, v ktorých sa aktívne používa nemecké nárečie, sú na Spiši a v Above. Oblasti Malých a Bielych Karpát, ktoré osídl'ovali Huncokári, sú dnes už jazykovo menej identifikovatel'né ako kompaktné územie s nemeckými jazykovými koreňmi. Napriek tomu existuje dostatok písomných zdrojov, ktoré dokumentujú toto nárečie, a zároveň je možné vd'aka obyvatel'om, ktorí toto nárečie ešte poznajú identifikovat' jeho charakteristické znaky (Fedič, 2014: 109-115).

Nárečia nemeckého jazyka môžeme členit' podl'a viacerých hl'adísk. Základným člením je rozdelenie nárečí na dolnonemecké nárečie, označované ako Plattdeutsch, a na hornonemecké nárečie, označované ako Hochdeutsch. Dolnonemecké nárečia sa používajú v severných nížinných oblastiach Nemecka. Hornonemecké nárečia môžeme d’alej rozčleňovat' na nárečia strednonemecké, ktoré sú označované aj ako Mitteldeutsch, a potom na nárečia horskonemecké, ktoré sú označované aj ako Oberdeutsch. Horskonemecké nárečia boli formované ovel'a výraznejšie vplyvom druhej fázy posunu hlások v nemčine v porovnaní s nárečiami zo stredného Nemecka. Horskonemecké nárečia sú vzájomne kontinuálne previazané, a tak nie je možná jednoznačná identifikácia hraníc ich používania ako tomu je pri hranici medzi Mitteldeutsch a Plattdeutsch. Horskonemecké nárečia rozdel'ujeme na severné, západné a východné. $\mathrm{K}$ východným horskonemeckým nárečiam, ktoré sa označujú aj ako bavorsko-rakúske, zarad’ujeme hornobavorské, stredobavorské a juhobavorské nárečie. Územie dnešného Rakúska a časti Bavorska, odkial' údajne pochádzajú aj horskí l’udia Huncokári, podl'a nárečia delíme na oblast', kde sa hovorí stredobavorským nárečím. V Tirolsku a Korutánsku sa hovorí juhobavorským nárečím.

Doterejšie analýzy a komparatívne výskumy tohto nárečia identifikovali vel'ké fonetické i sémantické podobnosti so stredobavorským nárečím v juhozápadných oblastiach dnešného Bavorska. S nárečiami z obastí dnešného Tirolska či Štajerska neboli identifikované žiadne zhody. Vel'a výrazov z huncokárskeho nárečia sa ešte i dnes používa $\mathrm{v}$ spomenutých bavorských lokalitách. Huncokársky jazyk a jeho aktívne používanie zanikli v polovici 20.storočia, z dôvodu strachu nositel'ov jazyka o svoj život a život svojich rodín najmä počas a po 2.sv. vojne. Treba pripomenút', že vzhl'adom na politickú situáciu v Československu, boli všetci, akokol'vek prislúchajúci $\mathrm{k}$ nemeckej menšine považovaní za zradcov a nepriatel'ov, boli násilne vysídl'ovaní, vyvražd'ovaní, odvlečení do pracovných táborov, Preto $\mathrm{v}$ mnohých rodinách rodičia zo strachu prestávali používat' huncokársky jazyk a neučili ho cielene ani svojich potomkov, resp. zakazovali det'om jazyk aktívne používat' a

XLinguae, Volume 11, Issue 3, June 2018, ISSN 1337-8384, eISSN 2453-711X 
prestali ho používat' i na komunikáciu v rodinách. Išlo teda o cielené a vedomé potláčanie a zabúdanie jazyka z dôvodu strachu o život a budúcnost'.

Až po roku 1989, resp. 1993, kedy boli menšinám priznané všeky práva a status, sa mohlo začat' otvorene hovorit' o potomkoch Nemcov na Slovensku /Československu, o ich identite, kultúre, jazyku, možnostiach revitalizácie a začat's vedeckými výskumami. Vzhl'adom na fakt, že Huncokári ako špecifická nemecká menšina nemá priznané práva menšiny na Slovensku, vzt’ahujú sa na nich len všeobecne práva platné pre nemeckú menšinu.

Nezaznamenali sme na Slovensku žiadne snahy o revitalizáciu tohto, či akéhokol'vek iného minoritného jazyka. Huncokársky jazyk je prakticky v komunite nepoužívaný od druhej svetovej vojny. V revitalizácii jazyka vidia dnes členovia skupiny a ich potomkovia vel'ký potenciál. Realizuje sa tým ich ústavné právo na používanie vlastného jazyka. Radi by jazyk používali nielen $\mathrm{v}$ rodinách, ale $\mathrm{v}$ budúcnoti aj vo verejnej sfére, kultúrnom a spoločenskom živote. Snom mnohých potomkov Huncokárov je osadenie tabúl' s názvami osád a obcí v dvojjazyčnej, resp. trojjazyčmej verzii (slovenský jazyk, nemecký a huncokársky jazyk), náučné chodníky a informačné tabule na architektonických a turistických pamiatkach $\mathrm{v}$ jazykových mutáciách (slovenský, nemecký, huncokársky); divadelné a hudobné predstavenia v ich jazyku. Prvým pokusom bolo naštudovanie krátkeho divadelného predstavenia (Naši Huncokári) klubom dôchodcov v Pezinku s krátkymi vsuvkami v jazyku Huncokárov v roku 2016. Budúcnost' vidíme v možnostich komunikácie členov skupiny $\mathrm{v}$ ich jazyku, vzdelávanie $\mathrm{v}$ jazyku, pozdvihnutie povedomia, identity formou prejavov vo vlastnom jazyku či aspoň aktívna komunikácia medzi členmi skupiny $\mathrm{v}$ ich jazyku.

Jazyk Huncokárov sa momentálne nachádza vo fáze "kriticky ohrozený" najmladší používatelia jazyka sú prestarlí (ročník 1930 a starší) a ich potomkovia sa jazyk aktívne nenučili, ani ho neovládajú. Pri analýze dát a snáh o revitalizáciu jazyka treba neustále pamätat' na fakt, že pracujeme s poslednými troma rodenými hovoriacimi, v anglickej literatúre často označovanými ako survivals, ktorí dokážu plynule jazykom hovorit' a majú vzhl'adom na svoj vek (ročníky 1930 a starší) ešte dobrú pamät' a komunikatívne zručnosti. Preto sú výskum jazyka a jeho dokumentácia $\mathrm{v}$ súčasnosti klúčovými aktivitami. Zdrojom pre vytvorenie korpusu huncokárskeho nárečia sú hlavne zvukové a obrazové záznamy, ktoré realizovali samotní potomkovia alebo sa realizujú výskumným tímom na pôde FF UCM od roku 2014. Ďalším zdrojom pre vstupné dáta do huncokárskeho korpusu sú listinné záznamy a zápisy tohto jazyka z minulých výskumov, amatérskych výskumov, ktoré sa realizovali.

Skupinu hovoriacich členov minority rozdel'ujeme do troch kategórii:

a) Rodení hovoriaci (native speakers)

Evidujeme posledných troch rodených hovoriacich, ročníky narodenia 1930 a starší. Všetci sa narodili v horách huncokárskym rodičom, od malička hovorili bilingválne (slovensko-huncokársky) až trilingválne Slovensko-nemecko-huncokársky). Chodili zväčša do nemeckej školy, doma s rodičmi a členmi komunity hovorili huncokársky, v škole sa najskôr učili nemecky, potom sa učili po slovensky. Jazyk ovládajú plynule, vedia vysvetlit' mnohé gramatické špecifiká jazyka a chápu a ovládajú rozdiely medzi spisovnou nemčinou a ich vlastným jazykom.

b) Pamätníci (remembers)

Do tejto skupiny patria hovoriaci členovia s vel’mi limitovanými znalost’ami fráz, kratších žánrov a pod. Zarad’ujeme sem potomkov huncokárov, ktorí už vzhl’adom na politickú situáciu $\mathrm{v}$ detstve navštevovali slovenské školy, mali doma zakázané používat' jazyk napriek tomu, že rodičia ním hovorili medzi sebou. Jazyk neovládajú aktívne, ale pamätajú si z detstva krátke frázy, piesne, krátke folklórne žánre, slovné spojenia. Tých je približne pät'desiat.

c) latentní noví hovoriaci (latent new speakers) 
Zarad’ujeme sem najmladšiu generáciu potomkov, ktorí jazyk neovládajú vôbec, nerozumejú mu, ale majú vel'ký záujem sa ho naučit', ako ho i naučit' svoje deti a použivat' ho pri komunikácii $\mathrm{v}$ skupine a rodine. Tých odhadujeme predbežne na stopät'desiat vo vybraných lokalitách. S touto skupinou máme intenzívne kontakty a v súčasnosti prebiehajú d’alšie mítingy a kontaktovanie potomkov v d’alších lokalitách, ako i potomkov odsunutých Huncokárov v Nemecku. Tí majú eminentný záujem o výučbu jazyka a pátrajú po svojich koreňoch.

Okrem týchto troch skupín, vychádzajúcich zo skupiny hovoriacich, treba upozornit' na skupinu nerodilých, nových hovoriacich, teda new speakers. Všeobecne nárast významu, často dynamických a aktivisticky orientovaných nových hovoriacich, sa zhruba na prelome 20. a 21.storočia stal natol'ko významným, že v súčasnosti je už tento fenomén významnou a pozorne sledovanou vetvou štúdia problematiky etnojazykovej revitalizácie. V nami skúmanom prostredí môžeme za skupinu nových hovoriacich pokladat' ako osoby vychádzajúce $\mathrm{z}$ dotknutej komunity, tak i záujemcov a sympatizantov "zvonka".Nie je pritom nutne spätá s etnickým pôvodom a identitou, ale napríklad s regionálnou príslušnost'ou, či len t’ažko definovanými symbolickými, resp. citovými väzbami a osobnými zál'ubami či náklonnost'ou (Šatava, 2017:324).

Skupina perspektívnych nových hovoriacich je vel'mi vel'ká, z radov potomkov, malých detí i z majority. $\mathrm{V}$ rodinách podl'a predbežných výskumov by podporili, uvítali a ocenili snahy a možnosti výučby jazyka formou kurzov, elearningu či mimoškolských aktivít. Možnost' znovu počut' a používat' jazyk predkov pokladajú za jedinečnú príležitost' posilnenia skupinovej identity a prejavy vlastnej kultúry na verejnosti. Majú záujem o divadelné predstavenie v jazyku, knihy i popularizačné texty pre potreby skupiny vo vlastnom jazyku. Rodičia majú eminentný záujem, aby ich deti aspoň čiastočne ovládali jazyk predkov.

A aký je dôvod tohto záumu? V čase rýchleho posunu a zanikania malých, regionálnych a menšinových jazykov, slúžia niektoré jazyky k vytváraniu identity vo vnútri komunity dokonca aj potom, kedy prestali byt' jazykom bežnej komunikácie. To sa deje pomocou mnohých kultúrnych praktík, ako napríklad amatérske divadlo, hudba a folklór, preklady, snahy o naučenie sa jazyka vo večerných kurzoch a podobne (Reershemius, 2009:131). V súčasnosti možno totiž pozorovat' výrazné posuny v chápaní jazyka, od „etnického aspektu“, t.z. jazyk chápaný ako znak či dokonca majetok určitého etnika; kd'aleko uvol'nenejšiemu konceptu jazyka, otvorenému všetkým adeptom a hovoriacim bez ohladu na ich etnický, resp. teritoriálny pôvod či sebaidentifikáciu. V tomto rámci sa celkovo prejavujú výrazné snahy o externú (kultúrnu, sociálnu, politickú, ekonomickú) difúziu autochtónnych jazykov prekračujúcu doterajšiu etnicko-teritoriálne poňatie či videnie (Šatava, 2017:325).

\section{Revitalizačné stratégie}

Revitalizácia má mnoho podôb a mnoho úskalí. Mala by prebiehat' prirodzene, nenásilne, bez tlakov a "revitalizačného inžinierstva", inak sa minie účinkom a výsledky budú značne skreslené. Revitalizácia by tiež mala prebiehat' obojsmerne, zvonka (od majority) a zvnútra (od samotných členov skupiny). Obojstranná väzba a spolupráca sú v tomto prípade nevyhnutné a jedna bez druhej budú neúspešné.

Dôležitými osobami na poli zberu dostupných materiálov ako podkladov pre proces revitalizácie sú však sami potomkovia Huncokárov. Snažia sa sami zachovat' čo najviac informácii z histórie, spôsobu života, jazyka a kultúry svojich predkov. Založili webový portál (www.huncokari.sk), kde sú zverejnené autentické výpovede Huncokárov, popisy lokalít, aktuality, správy zo života komunity a občianske združenie Huncokár, ktoré vlastní rozsiahly archív fotografii (viac ako 20 tisíc), nahrávok, výpovedí, rodokmeňov a má záujem o spoluprácu a spracovanie

XLinguae, Volume 11, Issue 3, June 2018, ISSN 1337-8384, eISSN 2453-711X 
problematiky. Každoročne sa stretávajú potomkovia niektorých rodín, kde si vymieňajú informácie, vystavujú artefakty z rodinných zbierok, fotografie, dopín̆ajú rodokmene. Výsledkom týchto stretnutí sú tri amatérske DVD dokumenty, výpovede najstarších pamätníkov o živote ich predkov ( z roku 2007, 2011 a 2013). Z týchto snáh vzišlo tiež viacero beletristických kníh a populárno-vedeckých článkov o živote Huncokárov. So všetkými organizáciami i jednotlivcami výskumný tím spolupracuje (Slobodová Nováková, 2016:28-37). Stratégie zamerané na revitalizáciu kultúry a jazyka huncokárskej komunity môžeme rozdelit' na dve skupiny aktivít. Jedna skupina vychádza zvnútra komunity a druhá $\mathrm{z}$ externého prostredia. $\mathrm{V}$ nami skúmanom prostredí medzi klúčových hráčov na poli revitalizácie patria:

- aktívni potomkovia Huncokárov so záujmom o znovuupevnenie vlastnej identity, revitalizáciu kultury a jazyka

- občianske združenia Huncokárov: OZ Huncokári (www.huncokari.sk), OZ Huncokári na Piesku, OZ Huncokári na Záhorí, OZ Potomkovia Huncokárov

- $\quad$ vedecký tím z UCM, ktorý realizuje záchranné etnografické, sociologické, historické a lingvistické výskumy v teréne a spolupracuje s OZ (NGO)

- mesto Modra, predstavitelia mestskej samosprávy so záujmom o podporu revitalizačních snáh, vytvorenie zázemia pre výskumný tím, podpora aktivít Huncokárov a vytvorenie podmienok pre implementáciu do prostredia mesta, kultúrneho a spoločenského života

Revitalizačné stratégie samotnej komunity (vznútra) majú za ciel' zabezpečit' možnost' znovuzískania vlastných členov komunity cez revitalizáciu jazyka a kultúry, resp. pôvodných členov a ich potomkov, ktorí stratili identitu (násilne) vplyvom politickej situácie, alebo (pasívne) prirodzeným odchodom starčích členov rodiny a komunity, bez možnosti kontinuity. Medzi cielené aktivity patria napríklad:

- $\quad$ prednášky, workshopy pre verejnost' realizované atívnymi členmi komunity a dalšie formy šírenia informací o tradíciách, materiálnej a duchovnej kultúry Huncokárov;

- organizovanie podujatí pre komunitu- Huncokárske hody, slávnosti lesa, slávnosti pri huncokárskej kaplnke, sviatky všetkých svätých na cintoríne Huncokárov(lokalita Modra-Piesok), náboženské púte na pôvodné miesta pútí predkov,organizácia kultúrnych festivalov, hudobné aktivity, produkcia na literárnom poli, divadelné predstavenia a iné

- Vznik krúžkov výuky jazyka; jazykové stretnutia rodených hovoriacich, resp. pamätníkov (,native speakers, remembers“) a záujemcov $\mathrm{z}$ radov potencionálnach nových hovoriacich (latentných) ,new speakers“

Revitalizačné stratégie mimo komunitu (zvonka) sa realizujú výskumným tímom etnológov, lingvistov, historikov a pedagógov, ide najmä o:

- vypracovanie gramatiky jazyka,

- $\quad$ vytvorenie abecedy hucnokárskeho jazyka vzhl'adom na fakt, že množstvo jazykových špecifík slovenská gramatika nedokáže zachytit'

- $\quad$ vypracovanie slovníka slovensko-nemecko-huncokárskeho

- $\quad$ vypracovanie učebných textov na výučbu základov jazyka

- vypracovanie pracovných zošitov

- $\quad$ vytvorenie e -learningových kurzov pre členov minority a verejnost' 
- $\quad$ workshopy, kurzy pre verejnost', pre potomkov a potencionálnach nových hovoriacich

- $\quad$ semináre na univerzitách, stredných školách v dotknutom regióne, kurzy huncokárskeho dialektu na univerzite

- $\quad$ slovníky distribuované medzi rodiny

Snahou o aplikáciu získaných dát je implementácia do vzdelávacieho systému; vytvorenie špeciálneho vzdelávacieho programu pre základné a stredné školy v dotknutom regióne, $\mathrm{v}$ rámci predmetu regionálna výchova, ako i výberový predmet huncokárskeho dialektu na jazykových germanistických katedrách na slovenských univerzitách.

Huncokárske nárečie ovládajú poslední hovoriaci a verejnost' nemá možnost' sa stretávat's týmto jazykom a nemá možnost' ho ani hodnotit'. Prvou príležitost'ou, ked' sa mohli záujemci mimo komunity Huncokárov stretnút' s týmto jazykom, boli jazykové aktivity realizované pracovníkmi UCM v roku 2017. Odvtedy prebehli už tri vzdelávacie semináre a workshopy pre verejnost' zamerané na zoznámenie sa s týmto huncokárskym nárečím a začalo sa s postupnou výukou. Materiály z výskumov sa už čiastočne využívajú a budú $\mathrm{v}$ elektronickej podobe využívat' i v podobe online aplikácie, d’alej formou tlačených printových médií, interaktívnych máp, online vzdelávacích kurzov prístupné cez web alebo mobilné zariadenia. Na realizáciu týchto krokov sa využívajú rôzne vol'ne dostupné počítačové programy a aplikácie, ako napr. Moodle alebo Kahoot.

\section{Zhrnutie}

V súčasnsoti u potomkov horských l'udí povedomie príslušnosti ku skupine prežíva bud' prostredníctvom individuálnej pamäte, alebo i ako súčast' kolektívnej pamäte dnešných lokálnych spoločenstiev žijúcich v blízkosti niekdajších sídiel. Pri realistickom pohl'ade na súčasnost' a minulost' Nemcov na Slovensku je práve výskum kultúry a spôsobu života nemeckej menšiny $\mathrm{v}$ malokarpatskej oblasti vel'mi potrebným, v mnohých ohl'adoch najmä záchranným výskumom miznúcej menšiny a jej potomkov.

Vedl'a čisto odbornej, dokumentačnej a jazykovo-kultúrnej roviny by sa dosiahnuté a zistené dáta, rovnako ako plánované revitalizačné aktivity, mali premietnut' do opätovného zviditel'nenia polozabudnutej huncokárskej tradície v malokarpatskom regióne a do zvýšenia vedomia a povedomia o multietnickom y multikultúrnom pozadí dotknutého regiónu. To však chce aktivitu všetkých dotknutých strán, teda zvonku i zvnútra, za podpory a pochopenia miest a obcí, vzdelávacích inštitúcii, spolkov a aktivistov. Vizuálne by tomu mohli napomôct' po vzore zo zahraničia dvojjazyčné nápisy, obsahujúce ,jazykovú krajinu“. V uvedených kontextoch je však treba vel'mi citlivo zvažovat' i možné dopady etnického /jazykového inžinierstva.

The scientific study is a partial result of the project APVV 15-0360: Rozmery revitalizácie etnickej minority na Slovensku.

www.projekthuncokari.sk

\section{Bibliographic references}

AUSTIN, P.K. - SALLABANK, J. (eds). 2011. The Cambridge Handbook of Endangered Languages. Cambridge: Cambridge University Press.

BRENZINGER, M. (ed). 2007. Language diversity Endangered. Berlin- New York: Mouton de gruyter.

BERANEK, F. J. 1943. Die deutsche Besiedlung der Westslowakei. In: Deutschtumsfragen in Nordkarpatenraum. Käsmark: Roland-verlag. Presburg. 
BOCANOVA, M. 2017. Moznosti a formy adaptacie socialne a ekonomicky vyluceneho obyvatelstva na periferii mesta do majoritnej spolocnosti (na priklade Trnavy). In: Narodopisna revue. vol 27, n.2, pp.114-127. ISSN 0862-8351

CUKAN, J. - KORINA, N. - LENOVSKY, L. 2014. Culture - Language - Identity (problem of relations) . In: XLinguae vol. 7, n. 4, pp. 21-32, ISSN 1337-8384,

EWAN Mc-FUJITA, E. 2011. Language revitalization discourses as metaculture: Gaelic in Scotland from the 18th to 20th centuries. In: Language \& Communication, vol. 31, n 1, pp.48-62. ISSN 0271-5309

FEDIC, D. 2014. Analysis of Huncokars Dielact. In. Etnologia Actualis, vol 14, n.2, pp.105-114. ISSN 1339-7834.

FISHMAN, J. A. 1991. Reversing Language Shift. Theoretical and Empirical Foundations od Assistance to Threatened Language. ClevedonPhiladelphia_Adelaide: Multilingual Matters Ltd.

HABANOVA, G. 1992. K niektorym problemom intra- a extraskupinovych vztahov drevorubacov tzv. Huncokarov v Malych Karpatoch. In: Zmeny v hodnotovych systemoch v kontexte kazdodennej kultury. Bratislava: ustav etnologie SAV, pp. 6685.

HARRISON, K.D. 2010. The last speakers. The Quest to Save the World's Most Endangered Languages. National Geografic Society.

HORNACEK BANASOVA, M. - DUJKOVA, S. - FEDIC, D. 2017, Tvorba ucebnice pre specialnu cielovu skupinu Huncokarov = Designing a textbook for the special target group of Huncokars. In: Schola nova, quo vadis? Praha : Extrasystem, 2017. - (Didaktika, pedagogika/Didactics, Pedagogy ; zv. 32), pp. $52-57$ [online]. ISBN 978-80-87570-38-8

KRAUSS, M. 1992. The world's languages in crisis. In: Language, vol 68, n.1, pp.410. ISSN 0097-8507

LENOVSKY, L. 2015. Identity as an instrument for interpreting the socio-cultural reality. In: European Journal of Science and Theology, Vol. 11, no. 5, pp. 171-184. ISSN 1841-0464

MAN-CHIU A. L. - YUDAW, B. 2013. Rethinking community-based Indigenous language revitalization using cultural-historical activity theory. In: Current Issues in Language Planning, vol. 14, n.3, pp. 436. ISSN 1747-7506

MORGAN, I. J. 2008. Redefining the Ojibwe Classroom: Indigenous Language Programs within Large Research Universities. In: Anthropology \& Education Quarterly, vol. 36, n.1, pp.96-103. ISSN: 01617761

NOVAKOVA, K. 2014. Study of Possibilities of Present-day Ethnic Revitalisation of German Woodsmen in the Little Carpatian. In: . Etnologia Actualis, vol 14, n.2, pp. 93-104. ISSN 1339-7834.

OLKO, J. - WICHERKIEWICZ, T. - BORGES, R. 2016. Integral Strategies for Language Revitalization. Warsaw: University of Warsaw.

O'ROUKE, B. - PUJOLA, J. - RAMALLO, F. 2015. New speakers of minority languages: the callengign, opportunity foreword. In: International journal of Sociology of Language, issue 231, pp.1-20. ISSN 1613-3668

PANCZOVA, Z. 2011. Zaniknuty svet malokarpatskych „Huncokarov“ v odraze poverovych rozpravani. In: Zaostrene na kulturne dedicstvo. Prierez starostlivostou o kulturne dedicstvo malokarpatskeho regionu. Zbornik prispevkov odborneho seminara. Svaty Jur: Academia Istropolitana Nova, pp. 14-22.

PAVLIKOVA, M. 2016. The concept of anxiety and its reflection in Auden's work 'the Age of Anxiety' In: European Journal of Science and Theology, vol. 12, n. 4, pp. 111-119. ISSN 1841-0464.

PAVLIKOVA, M. 2017. Reading Auden as a resource for existential reflection in a society with technocratic and hedonistic tendencies. In: Komunikacie, vol. 19, n. 1, pp. 39-43. ISSN 0341-2059. 
PRIECKO, M. 2015. Between Patriotism and Far-Right Extremism: A Case of Youth Activism in Matica slovenska. In: Ethnologia Actualis : the Journal of Ethnographical Research. vol 15, n.1, pp. 65-90. ISSN 1339-783

REERSHEMIUS, G. 2009. Post-Vernacular Language Use on a Low German Linguistic Community. In: Journal of German Linguistic, vol 21, n.2, pp.131-147. ISSN 1470-5427

SLOBODOVA NOVAKOVA, K. 2016. Malokarpatski Huncokari ako unikatna sucast europskeho a slovenskeho kulturneho dedicstva. In: Kulturne dedicstvo a identita : medzinarodna vedecka konferencia 25. - 26. maj 2016. Banska Bystrica : Belianum, 2016. pp. 28-37. ISBN 978-80-557-1120-1

SATAVA, L. 2013. Etnicita a jazyk. Teorie, praxe, trendy: citanka textu. Tribun EU.

SATAVA, L. 2017. „Novi mluvci“ v kontextu mensinovych jazyku v Evrope a revitalizacnich snah. In: Narodopisni revue. vol.27, n..4, pp.323-330. ISSN 0862-8351 TISLIAR, P. 2015. Cesta k prvemu uradnemu lexikonu sidel na Slovensku. In: uzeologia a kulturne dedicstvo, vol.3, n.1, pp.51-62. ISSN 1339-2204

Words: 5665

Characters: 41863 (23,26 standard pages)

Doc. Mgr. Katarína Slobodová Nováková, PhD.

Department of ethnology and World studies

Faculty of Arts

Ss. Cyril and Methodius University in Trnava

Námestie J. Herdu 2, Trnava

Slovakia

katarina.novakova@ucm.sk

PhDr. Katarína Koštialová, PhD.

Department of Social studies and Ethnology

Faculty of Arts

Matej Bel University

Cesta na amfiteáter 1, Banská Bystrica

Slovakia

katarina.kostialova@umb.sk

Mgr. Daniela Kušnierová

Department of ethnology and World studies

Faculty of Arts

Ss. Cyril and Methodius University in Trnava

Námestie J. Herdu 2, Trnava

Slovakia

daniela.kusnierova@ucm.sk

Mgr. Lukáš Kurajda

Department of ethnology and World studies

Faculty of Arts

Ss. Cyril and Methodius University in Trnava

Námestie J. Herdu 2, Trnava

Slovakia

lukas.kurajda@gmail.com 